\title{
Perbandingan Efektifitas Spiritual Emotional Freedom Technique dan Progressive Muscle Relaxation Untuk Meningkatkan Kualitas Tidur Penderita Hipertensi di Cilacap Selatan
}

\author{
Susilawati $^{1^{*}}$, Kasron $^{2}$ \\ 1. D-3 Kebidanan STIKES Al-Irsyad Al-Islamiyyah Cilacap \\ 2. S-1 Keperawatan STIKES Al-Irsyad Al-Islamiyyah Cilacap \\ *Email korespondensi: susilawati@stikesalirsyadclp.ac.id
}

\begin{abstract}
Abstrak
Penderita hipertensi sering mengeluhkan gangguan tidur seperti pusing atau sakit kepala. Tujuan penelitian ini adalah mengetahui perbandingan spiritual emotional freedom technique (SEFT) dan progressive muscle relaxation (PMR) terhadap kualitas tidur pasien hipertensi di Cilacap Selatan. Metode penelitian quasiexperiment dengan pendekatan dua kelompok pre-post-test. Responden penelitian adalah pasien hipertensi, pemilihan responden menggunakan purposive sampling, dengan kriteria penderita hipertensi yang mengikuti prolanis aktif, mampu melakukan aktivitas mandiri, mengkonsumsi obat hipertensi, melakukan SEFT dan PMR selama 7 hari. Responden diukur tingkat kualitas tidur menggunakan terjemahan Pittsburgh Sleep Quality Index (PSQI) sebelum perlakuan dan setelah pemberian intervensi. Analisis statistik menggunakan Mann-Whitney test. Sejumlah 32 responden memenuhi kriteria penelitian. Hasil penelitian menunjukan sebelum perlakuan SEFT sebanyak 43,8\% kategori kualitas tidur kurang baik dan 56,3\% sangat buruk. Setelah perlakuan sebanyak 25,0\% kategori agak baik dan 75,0\% kategori kurang baik. Sebelum perlakuan PMR sebanyak $43,8 \%$ kategori kualitas tidur kurang baik dan 56,3\% sangat buruk. Setelah perlakuan sebanyak 18,8\% kategori agak baik dan 81,3\% kategori kurang baik. Hasil analisis menunjukan bahwa terdapat perbedaan kualitas tidur setelah intervensi antara kelompok SEFT dan PMR dengan $p$-value 0,002. Kesimpulan penelitian adalah terdapat perbedaan kualitas tidur antara kelompok SEFT dan PMR setelah intervensi pada penderita hipertensi di Cilacap Selatan.
\end{abstract}

Kata kunci: hipertensi, kualitas tidur, progressive muscle relaxation, spiritual emotional freedom technique

\section{The Comparison of Spiritual Emotional Freedom Technique and Progressive Muscle Relaxation (PMR) to Increase Sleep Quality in Patients With Hypertension in South Cilacap City}

\begin{abstract}
Patients with hypertension patients can have sleep disorders such as dizziness or headache,. This study aimed to evaluate the effect of spiritual emotional freedom technique (SEFT) and progressive muscle relaxation (PMR) on sleep quality in patients with hypertension in South Cilacap City. The research used quasi-experiment with two group pre-post test group. Respondents were patients with hypertension, with the criteria forthose who were active in health care programme, able to perform independent activities, consume of anti-hypertensive drugs, have done SEFT and PMR regularly for 7 days. Pittsburgh Sleep Quality Index (PSQI) was used to evaluate sleep quality twice, before and 7 days after interventions SEFT. Statistic analysis used Mann-Whitney test. 32 respondents included in the criteria. The quality of sleep before treatment SEFT was $43.8 \%$ poor, $56.3 \%$ very bad. After treatment SEFT was $25 \%$ rather good, $75 \%$ less good. The quality of sleep before treatment PMR was $43.8 \%$ poor, $56.3 \%$ very bad. After treatment PMR was $18.8 \%$ rather good, $81.3 \%$ less good. The analysis shown the sleep quality was difference between SEFT and PMR after intervention with p-value 0.002. The study shows there is difference between SEFT and PMR after intervention in hypertensive patients in South Cilacap.
\end{abstract}

Keywords: hypertension, sleep quality, progressive muscle relaxation, spiritual emotional freedom technique 


\section{PENDAHULUAN}

Gangguan tidur merupakan suatu kumpulan kondisi yang dicirikan dengan adanya gangguan dalam jumlah, kualitas ataupun waktu tidur pada seseorang individu (Nagai \& Kario, 2012). Gangguan tidur yang terjadi pada seseorang dapat mempengaruhi kualitas tidurnya menjadi buruk. Kualitas tidur akan semakin buruk seiring dengan bertambahnya usia, karena seiring bertambahnya usia maka akan terjadi proses penuaan secara degenerative. Kualitas tidur yang buruk akan berpengaruh pada menurunnya produktivitas seseorang (Javaheri, Storfer-isser, Rosen, \& Redline, 2008). Gangguan tidur dapat terjadi pada seseorang yang menderita hipertensi. Pasien hipertensi yang mengalami gangguan tidur biasanya terbangun pada pagi hari dengan merasa pusing, sakit kepala, merasa lelah disiang hari, memperburuk kondisi pasien seperti kecemasan, gelisah, konsentrasi menurun, mudah tersinggung, dan dapat menimbulkan penyakit baru pada penderitanya seperti penyakit pembuluh darah koroner dan otak, obesitas, dan depresi (Persson, Clow, Edwards, Hucklebridge, \& Rylander, 2003).

Pasien dengan hipertensi biasanya memiliki kualitas tidur yang buruk, kualitas tidur yang buruk memiliki risiko lebih tinggi terjadinya hipertensi dibandingkan dengan kualitas tidur yang baik. Jika pasien hipertensi memiliki kualitas tidur yang buruk maka akan mempengaruhi tekanan darah pasien tersebut. Dimana tekanan darah akan meningkat dan akan memperburuk penyakit hipertensi yang dialami oleh pasien, sehingga kualitas tidur yang buruk pada pasien hipertensi harus diatasi (Javaheri et al., 2008).

Pada saat ini hipertensi merupakan faktor risiko ketiga terbesar yang dapat menyebabkan kematian dini. Hipertensi menyebabkan $62 \%$ penyakit kardiovaskular. Penyakit hipertensi diperkirakan akan terus meningkat setiap tahunnya dan pada tahun 2025, diperkirakan $29 \%$ atau 1,6 milyar orang di seluruh dunia akan mengalami hipertensi (Nadruz, 2015). Angka kejadian hipertensi di Kabupaten Cilacap menurut Dinkes Kabupaten Cilacap tahun 2014, hipertensi merupakan 10 penyakit terbanyak. Kasus terjadinya hipertensi di Kabupaten Cilacap pada tahun 2014 yaitu sebanyak 15.717 kasus, dengan hipertensi essensial 13.105 kasus. Di Puskesmas Cilacap
Selatan 2 terjadi kasus hipertensi sebanyak 571, dan pada tahun 2016 kasus hipertensi meningkat menjadi 819 kasus. Puskesmas Cilacap Selatan 2 mempunyai Prolanis yang dilaksanakan setiap 1 bulan sekali dan pada bulan Januari 2017 terdata 35 pasien lansia dengan hipertensi yang aktif mengikut prolanis yang dilaksanakan setiap satu bulan sekali (Dinas Kesehatan Kabupaten Cilacap, 2017).

Terapi yang bisa dilakukan untuk meningkatkan kualitas tidur dapat berupa nonfarmokologis yang dapat dilakukan dengan menggunakan relaksasi, sugesti, imajinasi, aromaterapi, terapi music, akupresure, dan terapi tertawa (G. de Niet, Tiemens, Lendemeijer, \& Hutschemaekers, 2009; G. J. De Niet, Tiemens, Kloos, \& Hutschemaekers, 2009). Salah satu teknik untuk meningkatkan kualitas tidur dapat teknik spiritual emotional freedom technique (SEFT). Terapi ini merupakan suatu teknik penggabungan dari sistem energi tubuh (energy medicine) dan terapi spiritualitas dengan menggunakan metode tapping (ketukan) beberapa titik tertentu pada tubuh. Banyak manfaat yang dihasilkan dengan terapi SEFT yang telah terbukti membantu mengatasi berbagai masalah fisik maupun emosi. Keunggulan terapi SEFT diantaranya yaitu tidak menimbulkan efek samping, lebih murah, lebih mudah, lebih aman, lebih cepat dan lebih sederhana, karena SEFT hanya menggunakan unsur spiritual dan tapping, yang secara medis tapping yang dilakukan juga tidak berbahaya. Sehingga terapi SEFT dapat dilakukan oleh siapapun (Vangsapalo, 2010; Zainuddin, 2009). Selain itu, terapi SEFT juga bersifat universal, artinya dapat digunakan berdasarkan latar belakang keyakinan pasien. Penelitian tentang penggunaan SEFT untuk kualitas tidur pernah dilakukan oleh (Rajin, 2015) pada pasien paska-operasi menunjukan terjadi peningkatan kualitas tidur setelah pemberian SEFT dengan p-value 0,009 pada hari pertama dan p-value $<0,001$ pada hari ketiga. (Rajin, 2015).

Salah satu teknik untuk relaksasi adalah teknik PMR Jacobson. PMR menurut Jacobson adalah suatu keterampilan yang dipelajari dan digunakan untuk mengurangi atau menghilangkan ketegangan serta menimbulkan rasa nyaman tanpa tergantung pada subjek diluar dirinya. PMR ini digunakan untuk mengurangi rasa cemas, 
stres, atau ketegangan. Dengan menegangkan sekelompok tertentu otot dan melemaskannya kembali dengan merasakan sensasi tegang dan sensasi rileks pada kelompok otot tersebut (Singh et. al, 2009). Penelitian yang dilakukan oleh Rahman (2014) tentang penggunaan PMR pada lansia yang mengalami gangguan kualitas tidur menunjukan PMR dapat meningkatkan kualitas tidur pada pasien lansia dengan $\mathrm{p}$-value 0,005 .

\section{METODE}

Penelitian ini merupakan jenis quasiexperiment dengan rancangan pre-post test without control group. Penelitian dilakukan di Cilacap Selatan, pada bulan Mei-Juni tahun 2017. Subjek penelitian adalah penderita hipertensi di Cilacap Selatan. Pemilihan responden menggunakan non-probability sampling dengan metode purposive sampling, dengan cara memilih sesuai dengan kriteria inklusi sampel:

a. Penderita hipertensi yang aktif mengikuti prolanis.

b. Mampu melakukan aktivitas mandiri.

c. Mengkonsumsi obat anti-hipertensi.

d. Melakukan SEFT teratur selama 7 hari.

Sedangkan kriteria ekslusi meliputi penderita hipertensi yang terdapat gangguan gerak osteoarthtritis maupun rheumatoid arthtritis. Dari total 35 responden penderita hipertensi, didapatkan besar sampel yang digunakan 16 responden kelompok SEFT dan 16 responden kelompok PMR. Responden diukur tingkat kualitas tidur menggunakan terjemahan Pittsburgh Sleep Quality Index (PSQI) sebelum perlakuan dan 7 hari setelah pemberian intervensi SEFT dan PMR. Analisis statistik menggunakan Mann-Whitney test.

\section{HASIL}

Tabel 1 Karakteristik Responden

Tabel 1

\begin{tabular}{llcccc}
\hline \multirow{2}{*}{ No } & \multirow{2}{*}{ Karakteristik } & \multicolumn{2}{c}{ SEFT } & \multicolumn{2}{c}{ PMR } \\
\cline { 3 - 6 } & & F & $\%$ & F & $\%$ \\
\hline \multirow{2}{*}{1} & Usia & & & & \\
& <60 Tahun & 7 & 43,7 & 6 & 37,4 \\
& 60-64 Tahun & 5 & 31,3 & 5 & 31,3 \\
\multirow{2}{*}{2} & >64 Tahun & 4 & 25,0 & 5 & 31,3 \\
& Jenis kelamin & & & & \\
& Perempuan & 12 & 75,0 & 13 & 81,2 \\
& Laki-laki & 4 & 25,0 & 3 & 18,8 \\
\hline
\end{tabular}

\begin{tabular}{llcccc}
\hline 3 & Pendidikan & & & & \\
& SD & 13 & 81,2 & 8 & 50,0 \\
& SMP & 0 & 0 & 3 & 18,8 \\
& SMA & 3 & 18,8 & 5 & 31,2 \\
\hline
\end{tabular}

Tabel 1 menunjukan pada kelompok SEFT sebagian besar responden berusia kurang dari 60 tahun $(43,7 \%)$, hampir seluruh responden perempuan $(75,0 \%)$ dan hampir seluruh responden berpendidikan SD $(81,3 \%)$. Pada kelompok PMR sebagian besar responden berusia kurang dari 60 tahun $(37,4 \%)$, hampir seluruh responden perempuan $(81,2 \%)$ dan separuh responden berpendidikan SD (50,0\%).

Tabel 2 Analisis Intervensi SEFT dan PMR dengan Kualitas Tidur

Tabel 2

\begin{tabular}{|c|c|c|c|c|c|c|}
\hline \multirow{2}{*}{ Kel } & \multirow{2}{*}{$\begin{array}{c}\text { Kualitas } \\
\text { Tidur }\end{array}$} & \multicolumn{2}{|c|}{ Pre } & \multicolumn{2}{|c|}{ Post } & \multirow{2}{*}{$p-v^{*}$} \\
\hline & & $\mathrm{F}$ & $\%$ & $\mathrm{~F}$ & $\%$ & \\
\hline \multirow[t]{5}{*}{ SEFT } & Sangat Baik & 0 & 0 & 0 & 0 & 0,001 \\
\hline & Agak Baik & 0 & 0 & 12 & 75,0 & \\
\hline & Kurang Baik & 9 & 56,3 & 4 & 25,0 & \\
\hline & Sangat & 7 & 43,8 & 0 & 0 & \\
\hline & Buruk & & & & & \\
\hline \multirow[t]{5}{*}{ PMR } & Sangat Baik & 0 & 0 & 0 & 0 & 0,001 \\
\hline & Agak Baik & 0 & 0 & 3 & 18,8 & \\
\hline & Kurang Baik & 7 & 43,8 & 13 & 81,3 & \\
\hline & Sangat & 9 & 56,3 & 0 & 0 & \\
\hline & Buruk & & & & & \\
\hline$p-v^{* *}$ & & & 486 & & 002 & \\
\hline
\end{tabular}

Ket: * Uji Wilcoxon; **Uji Mann-Whitney.

Tabel 2 menunjukan bahwa sebelum perlakuan SEFT $56,3 \%$ responden dengan kualitas tidur kurang baik dan $43,8 \%$ responden kualitas tidur sangat buruk. Setelah perlakuan SEFT $75 \%$ responden dengan kualitas tidur agak baik dan $25 \%$ kualitas tidur kurang baik, sebelum perlakuan PMR 43,8\% responden dengan kualitas tidur kurang baik dan 56,3\% responden kualitas tidur sangat buruk. Setelah perlakuan PMR 18,8\% responden dengan kualitas tidur agak baik dan 81,3\% kualitas tidur kurang baik, hasil analisis selanjutnya menunjukan bahwa terdapat perbedaan kualitas tidur setelah intervensi pada kelompok SEFT dan PMR dengan $p$ value 0,002 . 


\section{PEMBAHASAN}

Hasil penelitian menunjukan pada kelompok SEFT sebelum perlakuan sebanyak 43,8\% responden dengan kualitas tidur sangat buruk, sedangkan setelah perlakuan tidak ada responden yang dengan kualitas tidur sangat buruk. Pada kelompok PMR menunjukan sebelum perlakuan sebanyak $56,3 \%$ responden dengan kualitas tidur sangat buruk, sedangkan setelah perlakuan tidak ada responden yang dengan kualitas tidur sangat buruk. Hasil analisis menunjukan terdapat perbedaan kualitas tidur sebelum dan setelah perlakuan intervensi baik SEFT maupun PMR. Hasil analisis menunjukan sebelum intervensi SEFT dan PMR menunjukan tidak terdapat perbedaan kualitas tidur yang bermakna. Sedangkan setelah intervensi SEFT dan PMR menunjukan terdapat perbedaan kualitas tidur yang bermakna.

Hasil penelitian yang menunjukan tidak adanya perbedaan tingkat kualitas tidur antara kelompok PMR dan SEFT sebelum diberikan perlakuan. Pada kedua kelompok sama-sama mengalami gangguan tidur, hal ini dikarenakan pada pasien hipertensi memiliki kualitas tidur yang buruk karena adanya gejala yang menimbulkan ketidaknyamanan pada pasien hipertensi seperti sakit kepala, pusing, dan sulit bernafas. Hal ini sejalan dengan penelitian yang dilakukan Sagala (2011), yang menyebutkan $37 \%$ responden tidur pada malam hari 5-6 jam, lama waktu yang dibutuhkan untuk tertidur 3160 menit $(37 \%)$ dan frekuensi terbangun 1-2 kali $(60 \%)$.

$\begin{array}{crrr}\text { Hasil penelitian } & \text { sejalan } & \text { dengan } \\ \text { penelitian oleh Rajin } & (2015) & \text { tentang }\end{array}$
penggunaan SEFT pada pasien post-operasi untuk meningkatkan kualitas tidur pada pasien, yang menunjukan bahwa kualitas tidur pasien meningkat setelah diberikan SEFT dengan pvalue $<0,001$ (Rajin, 2015), serta penelitian tentang penggunaan SEFT pada pasien hipertensi yang dilakukan oleh Susanti (2015) menunjukan bahwa SEFT sendiri dapat menurunkan tekanan darah pada pasien hipertensi (Susanti, 2015).

Secara sederhana terapi SEFT merupakan tindakan kombinasi antara sugestirelaksasi dengan ketukan ringan (tapping) pada titik-titik meridian akupuntur. Sugesti-relaksasi berfokus pada kata atau kalimat yang diucapkan berulang kali dengan ritme yang teratur disertai sikap pasrah kepada Allah SWT. Penggunaan SEFT yang lebih berpengaruh terhadap kualitas tidur disebabkan karena dalam melakukan SEFT melibatkan unsur spiritual. Faktor spiritual sangat penting dan hal esensial yang merupakan hubungan vertikal hamba dengan Tuhan (Bekelman et al., 2010)

Ketika seorang pasien berdoa dengan tenang yang disertai dengan hati ikhlas dan pasrah, maka tubuh akan mengalami relaksasi dan menyebabkan seorang pasien menjadi tenang. Pernafasan menjadi teratur, denyut jantung menjadi teratur dan stabil yang akan melancarkan sirkulasi darah yang mengalir kedalam tubuh dan menyebabkan kondisi yang sangat nyaman dan rileks. Kondisi yang rileks dan tenang akan menurunkan kondisi kecemasan pada pasien sehingga menyebabkan rangsangan di koretks menurun yang akhirnya rangsangan Reticular Activating Sstem (RAS) menurun dan beberapa bagian Bulbar Synchronizing Region (BSR) mengambil alih yang dapat menyebabkan sensai kantuk yang menyebabkan seseorang mudah untuk mendapatkan tidur (Faridah, 2016; Javaheri et al., 2008; Persson et al., 2003).

Sementara itu ketukan ringan atau tapping yang dilakukan pada titik-titik energi meridian sesuai dengan teori gate control akan merangsang nyeri nociceptor yang dihantarkan ke korteks otak, yang akan membuka gerbang yang menyebabkan sensasi nyeri ketukan terasa di otak. Sensasi ketukan akan di rasakan diotak dan merangsang sistem RAS juga yang akan mempengaruhi tidur pasien. (Kaliyaperumal \& Gowri, 2010)

Selain itu, prosedur SEFT dilakukan dengan cara langsung mengetuk titik-titik yang sama dengan titik akupuntur. Prinsip dasar dari SEFT ini yaitu yakin, ikhlas, pasrah, syukur, dan khusyu. Ketika seseorang dalam keadaan yakin bahwa apa yang terjadi pada kehidupan ini adalah atas izin Allah SWT, dan semua kejadian dalam hidup ini adalah yang terbaik untuk dijalani. Yakin pada Maha kuasanya Allah SWT dan Maha sayangnya Allah pada mahluknya maka seseorang akan menjalani kehidupan ini dengan lebih tenang dan ringan (Faiz, 2008)

Terapi SEFT dapat mengatasi gangguan tidur karena terapi SEFT berfokus dengan kalimat yang berfokus pada doa sehingga tubuh akan mengalami relaksasi dan menyebabkan 
menjadi tenang. Saat melakukan SEFT akan terjadi peningkatan Hypothalamic Pituitary Adrenal (HPA) yang menyebabkan terjadi penghentian respon alarm dari system saraf simpatis bergantian dengan respon relaksasi dalam sistem saraf parasimpatis yang kemudian terjadi penurunan tingkat hormon kortisol dalam tubuh (Haynes, 2010). Kortisol memegang peranan penting dalam mengatur tidur, nafsu makan, fungsi ginjal, stres dan sistem imun. Saat melakukan SEFT maka akan menginhibisi hipotalamus untuk menghentikan sekresi Cortocotropin realising hormone (CRH) sehingga sekresi Adrenocorticotropic Hormone (ACTH) juga berhenti dan kadar kortisol akan menurun. Kadar kortisol yang menurun dapat membuat pasien merasakan rileks, menurunkan tekanan darah, dan mengatasi gangguan tidur. Respon relaksasi yang didapatkan karena menurunnya kadar kortisol akan mengakibatkan pernafasan dan denyut jantung menjadi teratur, sehingga sirkulasi darah yang mengalir kedalam tubuh menjadi lancar. Keadaan relaksasi menurunkan kecemasan pasien sehingga stimulus ke RAS menurun dan beberapa bagian, BSR mengambil alih yang dapat menyebabkan tidur (Faiz, 2008)

Hasil penelitian sejalan dengan penelitian oleh Saeedi et al. (2012) tentang penggunaan PMR untuk meningkatkan kualitas tidur pada pasien yang dilakukan hemodialisis, yang menunjukan bahwa kualitas tidur pasien meningkat setelah diberikan PMR dengan pvalue $<0,001$ (Saeedi et al., 2012). Sejalan dengan penelitian oleh Richardson (2003) tentang penggunaan PMR menunjukan pengaruh terhadap kualitas tidur pasien yang di rawat di bangsal kritis dengan penyakit terminal (Richardson, 2003). Penelitian lain oleh Sheu et al. (2003) tentang penggunaan PMR pada pasien hipertensi essensial menunjukan bahwa setelah intervensi 4 minggu pasien hipertensi mengalami penurunan ratarata $5,44 \mathrm{mmHg}$ untuk sistoloik, dan 3,48 $\mathrm{mmHg}$ untuk diastolic. Hasil menunjukan secara signifikan menurunkan tekanan darah pada pasien hipertensi (Sheu, Irvin, Lin, \& Mar, 2003).

PMR adalah kontraksi dan relaksasi berulang-ulang dari kelompok otot yang berbeda. Dengan melakukan penegangan dan pengenduran otot maka dapat menurunkan input dan output motor neuron, yaitu pada pre presinap akan menurunkan kontrol refleks $\mathrm{H}$ (proprioseptif) pada post sinap akan menurunkan kontrol refleks E (eksteroseptif). Penurunan proprioseptif dan ekteroseptif akan mengakibatkan penurunan motor evoked potensial (MEP) yang selanjutnya akan menurunkan aktifitas skeletal-motor system, sistem saraf otonom (simpatis dan parasimpatis) dan jaras kortikal (Guissard, Duchateau, \& Hainaut, 2001). Penurunan aktifitas skeletal-motor system dapat merelaksasikan sistem fisik seperti otot-otot tubuh. Pada sistem saraf otonom akan melibatkan sistem saraf simpatis dan sistem saraf parasimpatis. Beberapa organ dipengaruhi oleh kedua sistem saraf ini, aktifasi dari sistem saraf simpatik disebut juga erotropic atau respon figh or flight dimana efek dari saraf simpatis, yaitu meningkatkan denyut nadi, tekanan darah, hiperglikemia, dan dilatasi pupil, pernafasan meningkatkan, serta otot menjadi tegang. Aktivitas dari sistem saraf parasimpatis disebut juga trophotropic yang akan memanipulasi hipotalamus dengan menyebabkan rasa relaks dan lebih nyaman secara fisiologis dan emosional, serta dapat menyebabkan perasaan ingin istirahat, dan perbaikan fisik tubuh. aktivas ini merupakan dasar respon relaksasi dimana respon parasimpatik meliputi penurunan denyut nadi dan tekanan darah, perubahan fungsi neuroendokrin serta meningkatkan aliran darah. Oleh sebab itu melalui latihan relaksasi dapat memunculkan respon relaksasi sehingga dapat mencapai keadaan tenang. Penurunan pada jaras kortikal dan hipotalamus dapat menyebabkan sensasi rileks dan tenang secara psikologis emosional (Conrad \& Roth, 2007).

Mekanisme kerja progresive muscle relaxation dalam mempengaruhi kebutuhan tidur yaitu karena terdapat gerakan kontraksi dan relaksasi otot yang dapat menstimulasi respon relaksasi baik fisik maupun psikologis. Ketika melakukan gerakan relaksasi otot, sebuah sel syaraf juga mengeluarkan opiate peptides dan dialirkan keseluruh tubuh sehingga yang dirasakan adalah rasa nikmat dan rileks. Adanya respon relaksasi trophotropic akan menstimulasi sistem saraf. Dimana fungsi sistem saraf berlawanan dengan sistem saraf simpatis sehingga tercapai keadaan rileks dan tenang. Perasaan rileks ini akan diteruskan ke hipotalamus sehingga 
hipotalamus menghasilkan Corticotropin Releasing Factor (CRF). CRF akan menstimulasi kelenjar pituitary sehingga produksi beberapa hormone akan meningkat, seperti $\beta$-endorphin, enkefalin dan serotonin. Secara fisiologis, kebutuhan tidur akan terpenuhi karena akibat dari penurunan aktivitas Reticular Activating System (RAS) dan noreepineprine sebagai akibat penurunan aktivitas sistem batang otak. Respon relaksasi akan terjadi karena adanya aktifitas sistem saraf otonom parasimpatis nuclei rafe. Hal ini akan menyebabkan perubahan yang dapat mengontrol aktivitas sistem saraf otonom berupa pengurangan fungsi oksigen, frekuensi nafas, denyut nadi, ketegangan otot, tekanan darah, serta gelombang alfa dalam otak sehingga mudah untuk tertidur (Brunelli et al., 2015).

Progressive muscle relaxation dapat mempengaruhi tidur karena saat melakukan PMR akan memunculkan respon relaksasi (Trophotropic) yang menstimulasi semua fungsi dimana kerjanya berlawanan dengan system saraf simpatis sehingga tercapai keadaan rileks dan tenang. Perasaan rileks akan menghasilkan Corticotropin Releasing Factor $(C R F)$ sehingga meningkatkan produksi beberapa hormone, seperti $\beta$-Endorphin, Enkefalin dan Serotonin (Ramdhani, 2008). Secara Fisiologis, terpenuhinya kebutuhan tidur terjadi karena penurunan aktifitas Reticular Activating System (RAS) dan noreepineprine sebagai akibat penurunan aktivitas sistem batang otak, sebagai akibat dari penurunan aktivitas Reticullar Activating System (RAS) dan peningkatan aktivitas batang otak akan menimbulkan sensasi nyaman sehingga merangsang timbulnya kantuk. (Feldman, Greeson, \& Senville, 2010).

Walaupun adanya perbandingan antara SEFT dan PMR, namun kedua terapi ini dapat meningkatkan kualitas tidur pada pasien hipertensi. Secara statistik menunjukan adanya perbedaan yang bermakna antara kedua intervensi tersebut. Demikian juga secara proporsi menunjukan pada kelompok SEFT menunjukan persentase kualitas tidur yang lebih tinggi tingkatannya disbanding pada kelompok PMR, namun demikian perlu adanya penelitian lanjutan untuk mengetahui tingkat kemaknaan tersebut pada tempat dan responden yang lain.
Hasil penelitian menunjukan terdapat perbedaan tingkat kualitas tidur antara kelompok SEFT dan PMR setelah diberikan intervensi pada penderita hipertensi di Cilacap Selatan, sehingga disarankan penderita hipertensi dapat melakukan tindakan SEFT maupun PMR untuk meningkatkan kualitas tidur yang terganggu akibat dari hipertensi yang diderita.

\section{SIMPULAN}

Terdapat perbedaan efektifitas penggunaan spiritual emotional freedom technique dan progressive muscle relaxation terhadap peningkatan kualitas tidur pada penderita hipertensi di Cilacap Selatan.

\section{SARAN}

Perlu intervensi untuk meningkatkan kualitas tidur dengan intervensi mandiri seperti penggunaan SEFT dan PMR pada penderita hipertensi di Cilacap Selatan.

\section{DAFTAR PUSTAKA}

Bekelman, D. B., Parry, C., Curlin, F. a., Yamashita, T. E., Fairclough, D. L., \& Wamboldt, F. S. (2010). A Comparison of Two Spirituality Instruments and Their Relationship With Depression and Quality of Life in Chronic Heart Failure. Journal of Pain and Symptom Management, 39(3), 515-526.

https://doi.org/10.1016/j.jpainsymman.200 9.08.005

Brunelli, S., Morone, G., Iosa, M., Ciotti, C., Giorgi, R. De, Foti, C., \& Traballesi, M. (2015). Efficacy of Progressive Muscle Relaxation , Mental Imagery , and Phantom Exercise Training on Phantom Limb: A Randomized Controlled Trial. Archives of Physical Medicine and Rehabilitation, 8-12. https://doi.org/10.1016/j.apmr.2014.09.03 5

Conrad, A., \& Roth, W. T. (2007). Muscle relaxation therapy for anxiety disorders: It works but how? Journal of Anxiety Disorders, 21(3), 243-264. https://doi.org/10.1016/j.janxdis.2006.08.0 01 
de Niet, G., Tiemens, B., Lendemeijer, B., \& Hutschemaekers, G. (2009). Musicassisted relaxation to improve sleep quality: meta-analysis. Journal of Advanced Nursing, 65(7), 1356-1364. https://doi.org/10.1111/j.1365-

2648.2009.04982.x

Dinas Kesehatan Kabupaten Cilacap. (2017). Laporan Tahunan Penyakit Tidak Menular (PTM). Cilacap.

Faiz, Z. (2008). Spiritual Emotional Freedom Technique For Healing, Succes, Happiness, Greatness (Revision 2). Jakarta: Afzan Publishing.

Faridah, V. N. (2016). Perubahan Persepsi Dan Domain Spiritual Terhadap Tekanan Darah Penderita Hipertensi Akibat Pemberian Spiritual Emotional Freedom Technique (SEFT) Virgianti Nur Faridah. Surya, 8(1), 60-71.

Feldman, G., Greeson, J., \& Senville, J. (2010). Behaviour Research and Therapy Differential effects of mindful breathing , progressive muscle relaxation, and loving-kindness meditation on decentering and negative reactions to repetitive thoughts. Behaviour Research and Therapy, 48(10), 1002-1011. https://doi.org/10.1016/j.brat.2010.06.006

Guissard, N., Duchateau, J., \& Hainaut, K. (2001). Mechanisms of decreased motoneurone excitation during passive muscle stretching. Experimental Brain Research, 137(2), 163-169. https://doi.org/10.1007/s002210000648

Javaheri, S., Storfer-isser, A., Rosen, C. L., \& Redline, S. (2008). Sleep Quality and Elevated Blood Pressure in Adolescents. Circulation, 118, 1034-1040. https://doi.org/10.1161/CIRCULATIONA HA.108.766410

Kaliyaperumal, R., \& Gowri, J. (2010). Effect of music therapy for patients with cancer pain. International Journal of Biological \& Medical Research, 3(3), 79-81.
Nadruz, W. (2015). Myocardial remodeling in hypertension. Journal of Human Hypertension, 29(1), 1-6. https://doi.org/10.1038/jhh.2014.36

Nagai, M., \& Kario, K. (2012). [Sleep disorder and hypertension]. Nihon Rinsho. Japanese Journal of Clinical Medicine, 70(7), 1188-1194. Retrieved from http://europepmc.org/abstract/MED/22844 803

Niet, G. J. De, Tiemens, B. G., Kloos, M. W., \& Hutschemaekers, G. J. M. (2009). Review of systematic reviews about the efficacy of non-pharmacological interventions to improve sleep quality. International Journal Evidence Based Healthcare, 7, 233-242. https://doi.org/10.1111/j.17441609.2009.00142.x

Persson, K., Clow, A., Edwards, S., Hucklebridge, F., \& Rylander, R. (2003). Effects of nighttime low frequency noise on the cortisol response to awakening and subjective sleep quality. Life Science, 72, 863-875.

Rajin, M. (2015). Terapi Spiritual Emotional Freedom Technique ( SEFT ) Untuk Meningkatkan Kualitas Tidur Pasien Pasca Operasi di Rumah Sakit. Jurnal Lembaga Penelitian Universitas Pesantren Tinggi Darul Ulum Jombang, $1-5$.

Richardson, S. (2003). Effects of Relaxation and Imagery on the Sleep of Critically Ill Adults. Dimensions of Critical Care Nursing, 22(4), 182-190.

Saeedi, M., Ashktorab, T., Saatchi, K., Zayeri, F., Amir, S., \& Akbari, A. (2012). The Effect of Progressive Muscle Relaxation on Sleep Quality of Patients Undergoing Hemodialysis. Iranian Journal of Critical Care Nursing, 5(1), 23-28.

Sheu, S., Irvin, B. L., Lin, H.-S., \& Mar, C.-L. (2003). Effects of Progressive Muscle Relaxation on Blood Pressure and Psychosocial Status for Clients with 
Essential Hypertension in Taiwan. Holistic Nursing Practice, 17(1). Retrieved from http://journals.lww.com/hnpjournal/Fullte xt/2003/01000/Effects_of_Progressive_M uscle_Relaxation_on_Blood.9.aspx

Singh, V. P., Rao, V., V, P., R C, S., \& K, K. P. (2009). Comparison of the effectiveness of music and progressive muscle relaxation for anxiety in COPD--A randomized controlled pilot study. Chronic Respiratory Disease, 6(4), 209-216. https://doi.org/10.1177/147997230934674

Susanti, D. (2015). Pengaruh Spiritual Emotional Freedom Technique ( Seft) Terhadap Penurunan Tekanan Darah Pada Penderita Hipertensi Di Wilayah Kerja Puskesmas Pauh Kota Padang. Universitas Andalas.

Vangsapalo, D. (2010). Emotional freedom technique (EFT): terapi modern yang mengubah hidup anda. Tangerang: Tanggerang: Quantum Succes Training \& Coaching.

Zainuddin, F. A. (2009). SEFT for Healing, Success, happiness, Greatness. Timur. Jakarta: Afzan Publishing: Jakarta. 